\title{
Civilisation, dialogue, security: the challenge of post-secularism and the limits of civilisational dialogue
}

\author{
PINAR BILGIN
}

\begin{abstract}
The purposes of this article are twofold: (1) to consider the extent to which Dialogue of Civilisations (DoC) initiatives, as alternative visions of post-secular world order, are likely to address insecurities that they identify; and (2) to point to other insecurities that are likely to remain unidentified and unaddressed in the process. In their present conception, DoC initiatives risk falling short of addressing the very insecurities they prioritise (the stability of inter-state order) let alone attending to those experienced by non-state referents, which they overlook. The article advances three points in three steps. First, I point to how projects of civilisational dialogue have bracketed civilisation, thereby leaving intact the Huntingtonian notion of civilisations as religiously unified autochthonous entities. Second, I argue that while contributing to opening up space for communication, DoC initiatives have nevertheless failed to employ a dialogical approach to dialogue between civilisations. Third, I tease out the notion of security underpinning DoC initiatives and argue that the proponents DoC, in their haste to avert a clash, have defined security narrowly as the absence of war between states belonging to different civilisations. Theirs is also a shallow notion of security insofar as it fails to capture the derivative character of security and insecurity.
\end{abstract}

Pinar Bilgin is Associate Professor of International Relations at Bilkent University, Turkey. She is the author of Regional Security in the Middle East: a Critical Perspective (Routledge, 2005). Her articles have appeared in Political Geography, European Journal of Political Research, Third World Quarterly, Security Dialogue, International Political Sociology, Foreign Policy Analysis; and Geopolitics among others. She is an Associate Member of the Turkish Academy of Sciences, and an Associate Editor of Security Dialogue and International Political Sociology. Her research agenda focuses on critical approaches to security studies.

The secularisation thesis (which anticipated secularism gaining a stronger foothold worldwide in tandem with modernisation) no longer commands the kind of authority it once did as the way for ordering domestic polities and world politics. There is also mounting empirical evidence pointing to the ways in which religion has continued to shape the identities and practices of people in various parts of the world - including those whose social and/or political orders have gone through secularisation. Such evidence is considered by some as disproving the secularisation thesis and signalling the dawn of a post-secular era for world politics. ${ }^{1}$

${ }^{1}$ Peter L. Berger (ed.), The Desecularisation of the World: Resurgent Religion and World Politics (Washington, DC: Ethics and Policy Center, 1999); Peter L. Berger, 'Reflections on the Sociology of Religion Today', Sociology of Religion, 62:4 (2001), pp. 443-54. 
Still, these considerations may have less to do with the substance of the secularisation thesis, or empirical evidence, but a change in consciousness. Writing about the Northern sphere, Jürgen Habermas has attributed such change in public consciousness to broad perception that contemporary conflicts are rooted in religious differences; that religion is increasingly becoming influential in shaping domestic polities; and that religious difference has come closer to home following an increase in the numbers and diversity of immigrants and refugees. ${ }^{2}$ In the global sphere, there is increasing awareness of the persistence of religious worldviews; their efficacy in shaping domestic and foreign policies of different actors around the world (including non-state actors); and the limitations of existing world order norms in addressing possible consequences of such difference. ${ }^{3}$

While it is by no means a foregone conclusion that a post-secular world order would be characterised by insecurity, the tone of present-day debates suggests otherwise. Since the 1979 revolution in Iran, the so-called 'return' of religion has been portrayed as an ill omen for world security. Consider Daniel Pipes's polemical essay from 1990 entitled 'The Muslims are Coming! The Muslims are Coming!' that pointed to religious difference as a source of insecurity for the United States both internally (immigration) and internationally (relations with Muslim powers). Also consider Samuel P. Huntington's 1993 essay entitled 'The Clash of Civilizations?' where the author warned about desecularisation of the world as an ominous trend leading toward a clash of states belonging to different civilisations (defined largely along religious lines by the author).$^{5}$

Such concerns, in turn, have their roots in an often-unacknowledged bond between secularism and security. ${ }^{6}$ Secularisation of Western Europe is generally considered as having brought confessional violence of early modern eras to an end. ${ }^{7}$ Now that the secularisation thesis is waning, disquiets have been voiced about possible reoccurrence of such kind of violence. Of those concerned about the challenge of post-secularism for security, while some (such as Pipes and Huntington) have warned about a coming clash and called for strengthening one's own (internally and internationally),

2 Jürgen Habermas, 'Religion in the Public Sphere', European Journal of Philosophy, 14:1 (2006), pp. 125; Jürgen Habermas, 'Secularism's Crisis of Faith', New Perspectives Quarterly (Fall 2008), pp. 16-29.

3 Rajeev Bhargava (ed.), Secularism and its Critics (Delhi: Oxford University Press, 1998); Rajeev Bhargava, 'States, Religious Diversity, and the Crisis of Secularism', openDemocracy \{www.opendemocracy.net\} accessed 22 March 2011.

${ }^{4}$ Daniel Pipes, 'The Muslims are Coming! The Muslims are Coming!', National Review (November 1990), pp. $28-31$.

5 Huntington's article came out in the US policy magazine Foreign Affairs in 1993. Three years later he published the book length version. While the book's style was more nuanced than the article regarding the inevitability of a clash, the disappearance of the question mark in the title suggested that the author was no less confident of his conclusions. See, Samuel P. Huntington, 'Clash of Civilizations?', Foreign Affairs, 72:3 (1993) pp. 22-49; Samuel P. Huntington, The Clash of Civilizations and the Remaking of World Order (New York: Simon \& Schuster, 1996).

${ }^{6}$ Michael C. Williams, 'Identity and the politics of security', European Journal of International Relations, 4:2 (1998), pp. 204-25; Pinar Bilgin, 'The Securityness of secularism? The case of Turkey', Security Dialogue, 39:6 (2008), pp. 593-614.

7 But see, Carsten Bagge Lautsen and Ole Wæver, 'In Defense of Religion: Sacred Referent Objects for Securitization', in Pavlos Hatzopoulos and Fabio Petito (eds), Religion in International Relations: The Return from Exile (London: Palgrave Macmillan, 2003), pp. 147-80; Luca Mavelli, 'Security and secularization in International Relations', European Journal of International Relations, 18:1 (2011), pp. 177 99. 
others (as with Habermas) have pointed to the shortcomings of secularism in responding to contemporary challenges and called for envisioning alternative post-secular orders. ${ }^{8}$

The purposes of this article are twofold: (1) to consider the extent to which such alternative visions of post-secular world order are likely to address insecurities they identify; and (2) to point to other insecurities that are likely to remain unidentified and unaddressed in the process. Toward this end, I focus on one specific vision of post-secular world order, namely Dialogue of Civilisations (DoC). DoC refers to the combined efforts of a group of state and non-state actors toward generating unfettered communication between those belonging to different 'civilisations'. Although civilisational dialogue initiatives are no more than 'a set of ideas, which are often generic but increasingly perceived as a political necessity all over the world to somehow contribute to a more peaceful and just world order', ${ }^{9}$ they are increasingly offered as our best response in light of the challenge of post-secularism. ${ }^{10}$

That said there is no agreement, as yet, among proponents of DoC regarding what post-secularism means for them. While academic writings have appreciated the project of $\mathrm{DoC}$ as an embodiment of the spirit of post-secularism, state level DoC practices have come to constrain such ideas. Whereas academic authors have encouraged delving deeper into the meaning(s) of post-secularism and 'question and probe the concept of the secular, and to re-interrogate the whole "faith versus reason" problematic that has so consistently punctuated modern thought"11 (including notions of in/security), state-level representations of DoC have given way to an impression of post-secularism as tantamount to insecurity.

The following argues that, as alternative visions of post-secular world order, DoC initiatives risk falling short of addressing those insecurities they prioritise (that is, the stability of inter-state order), let alone attending to those experienced by non-state referents, which they overlook. The article advances three points in three steps. First, I point to how projects of civilisational dialogue have bracketed civilisation, thereby leaving intact the Huntingtonian notion of civilisations as religiously unified autochthonous entities. Second, building on a Bakhtinian notion of dialogue, I argue that while contributing to opening up space for communication, DoC initiatives have

${ }^{8}$ For elaborations on Habermas, see, Mariano Barbato, 'Conceptions of the Self for Post-secular Emancipation: Towards a Pilgrim's Guide to Global Justice', Millennium - Journal of International Studies, 39:2 (2010), pp. 547-64; Olav Hevdelien, 'Post-Secular Consensus? On the Munich-dialogue between Joseph Ratzinger and Juergen Habermas', Australian eJournal of Theology, 18:2 (2011), pp. 107-16.

9 Fabio Petito, 'Dialogue of Civilizations As An Alternative Model for World Order', in Michalis S. Michael and Fabio Petito (eds), Civilizational Dialogue and World Order: The Other Politics of Cultures, Religions, and Civilizations in International Relations (New York: Palgrave Macmillan, 2009), p. 47.

10 Marc Lynch, 'The Dialogue of Civilisations and International Public Spheres', Millenium: Journal of International Studies, 29:2 (2000), pp. 307-30; Fred Dallmayr, Dialogue Among Civilizations: Some Exemplary Voices (New York: Palgrave Macmillan, 2002); Michalis S. Michael and Fabio Petito (eds), Civilizational Dialogue and World Order: The Other Politics of Cultures, Religions, and Civilizations in International Relations (New York: Palgrave Macmillan, 2009); Fabio Petito, 'In Defence of Dialogue of Civilizations: With a Brief Illustration of the Diverging Agreement between Edward Said and Louis Masignon', Millennium: Journal of International Studies, 39:3 (2011), pp. 759-79.

11 Gregor McLennan, 'Towards Postsecular Sociology?', Sociology, 41:5 (2007), p. 859. As Petito and Hatzopoulos have argued, such debates would allow inquiry into prevalent assumptions about the proper relationship between the sacred and the profane that has made Huntington's thesis possible. Be that as it may, my aim here is to discuss the limitations of $\mathrm{DoC}$ as one response to the challenge of postsecularism, but not to interrogate the conditions of possibility of that challenge. See, (Fabio Petito and Pavlos Hatzopoulos, 'The Return from Exile: An Introduction' in Petito and Hatzopoulos (eds), Religion in International Relations, pp. 1-20. 
nevertheless failed to employ a dialogical approach to dialogue between civilisations. Third, I tease out the notion of security underpinning DoC initiatives and argue that the proponents DoC, in their haste to avert a clash, have defined security narrowly as the absence of war between states belonging to different civilisations. Theirs is also a shallow notion of security in so far as it fails to capture the derivative character of security and insecurity. This threefold conceptual limitation, I argue, does not allow fostering dialogue. Such failure to fulfil the promise of dialogue, in turn, is a manifestation of the limitations of DoC as an alternative vision of post-secular world order.

Limitations of DoC initiatives become apparent when judged not only by the standards their proponents set for themselves but also by the standards of critical approaches to security. ${ }^{12}$ This is not only because they privilege the stability of world order over and above non-state referents, but also because they lack sociological insights into power/knowledge dynamics within civilisations, which, in turn, allows them to overlook myriad insecurities experienced by non-state referents. Whereas considering civilisations in relationist (as opposed to essentialist) and dialogically constituted (as opposed to autochthonous) terms, while paying due attention to non-state referents and their myriad insecurities (as opposed to relying on a statist and military-focused conception of security) would likely allow a sounder response in light of the challenge of post-secularism.

Two caveats are in order: First, the following defines post-secularism as understood in present-day policy discourse. I have limited my task here to discussing those challenges tied up with above-mentioned change in consciousness regarding secularism and insecurities that are feared to follow - but not the constitutive effects of the 'secular' and the 'religious' on security. That said, if José Casanova is correct in arguing that secularisation in Western Europe 'can be better explained in terms of the triumph of the knowledge regime of secularism' through the Enlightenment's 'ideological critique of religion' as opposed to structural socioeconomic factors alone, ${ }^{13}$ then, emergence of a knowledge regime of post-secularism could potentially have important consequences for the future of secularism.

The second caveat is regarding the apparent persistence of religion and/or decline of secularism; empirical evidence does not speak for itself. To quote Maeve Cooke, 'the persistence of religious world views in secularized social orders can just as easily be taken as an argument for a secular political domain as for a post-secular one'. ${ }^{14}$ Furthermore, the secularisation thesis rests on a particular definition of secularism

12 My aim here is not to unpack 'security'. Critical security studies offer multiple ways for approaching security critically. In what follows, I will be building upon the insights of critical security studies to problematise the notion of security DoC projects have built upon. On critical security studies see, for example, Ken Booth, 'Security and Emancipation', Review of International Studies, 17:4 (1991), pp. 313-26; Barry Buzan, People, states, and fear: an agenda for international security studies in the post-cold war era (New York: Harvester Wheatsheaf, 1991); Ronnie D. Lipschutz (ed.), On Security (New York: Columbia University Press, 1995); Keith Krause and Michael C. Williams (eds), Critical Security Studies: Concepts and Cases (Minneapolis, MN: University of Minnesota Press, 1997); Barry Buzan, Ole Wæver and Jaap de Wilde, Security: a new framework for analysis (Boulder, Colo.: Lynne Rienner Pub., 1998); Ken Booth, Theory of World Security (Cambridge: Cambridge University Press, 2007).

13 Jose Casanova, 'Religion, European Secular Identities, and European Integration', in Timothy A. Byrnes and Peter J. Katzenstein (eds), Religion in an Expanding Europe (Cambridge: Cambridge University Press, 2006), p. 84

14 Maeve Cooke, 'A Secular State for a Postsecular Society? Postmetaphysical Political Theory and the Place of Religion', Constellations, 14:2 (2007), pp. 224-38. 
(as 'the process of religious decline') whereas experiences worldwide reveal the existence and persistence of a plurality of secularisms in theory and practice. Accordingly, the decline of the secularisation thesis need not be taken to mean the decline of secularism. In view of that, Rajeev Bhargava has lately called for 'improving' our current understanding of secularism based on the 'best practices' of existing secular systems in different parts of the world - as opposed to, that is, 'getting stuck on models ... developed at a particular point in [Western] history' and lamenting their decreasing relevance for contemporary world politics. ${ }^{15}$ Failing to heed Bhargava's plea, contributors to recent debates seem to have taken for granted the impending dawn of a post-secular era, as they point to the shortcomings of secularism in responding to contemporary challenges of world politics and the need for alternative postsecular orders. ${ }^{16}$ This article seeks to contribute to this literature by way of highlighting the limitations of one particular model of post-secular world order.

The article begins by presenting a brief overview of the clash thesis and state-level DoC initiatives. The three sections that follow highlight the threefold limitation of DoC initiatives in conceptualising the notions of civilisation, dialogue, and security.

\section{Do not clash; have dialogue}

The academic discipline of International Relations (IR) came into being in the context of two destructive world wars, as a 'modern' social science built upon assumptions of the secularisation thesis. ${ }^{17}$ In the face of the 1990s' so-called 'return' of religion, IR was not equipped to address religious or other forms of 'difference'. ${ }^{18}$ Consequently, it was Huntington's clash thesis that carried the day in the 1990s by offering a way of making sense of the apparent return of religion albeit within an all-too-familiar Cold War 'us vs. them' framework.

Notwithstanding its scientific limitations, ${ }^{19}$ Huntington's clash thesis has had a life outside the scholarly realm, being picked up by pundits and policymakers in different parts of the world. ${ }^{20}$ Conversely, some other opinion- and policymakers worried about Huntington's thesis becoming a self-fulfilling prophecy. Such concerns

15 Bhargava, 'States, Religious Diversity, and the Crisis of Secularism'.

16 See, for example, Fabio Petito and Pavlos Hatzopoulos (eds), Religion in International Relations: The Return from Exile (London: Palgrave Macmillan, 2003); Friedrich V. Kratochwil, 'Religion and (inter-) national politics: On the heuristics of identities, structures, and agents', Alternatives, 30:2 (2005), pp. 113-40; Timothy A. Byrnes and Peter J. Katzenstein (eds), Religion in an expanding Europe (Cambridge, UK; New York: Cambridge University Press, 2006); Barbato, 'Conceptions of the Self for Post-secular Emancipation', pp. 547-64. But see Pasha in this Special Issue.

17 Vendulka Kubálková, 'Towards an international political theology', Millennium-Journal of International Studies, $29: 3$ (2000), pp. 675-704; Petito and Hatzopoulos (ed.), Religion in International Relations; Friedrich Kratochwil, 'Religion and (inter-)national politics: On the heuristics of identities, structures, and agents', Alternatives, 30:2 (2005), pp. 113-40.

18 Naeem Inayatullah and David L. Blaney, International Relations and the Problem of Difference (London: Routledge, 2004).

19 Errol A. Henderson and Richard Tucker, 'Clear and Present Strangers: The Clash of Civilizations and International Conflict', International Studies Quarterly, 45:2 (2001), pp. 317-38; Giacomo Chiozza, 'Is There a Clash of Civilizations? Evidence from Patterns of International Conflict Involvement, 1946-97', Journal of Peace Research, 39:6 (2002); Erik Gartzke and Kristian Skrede Gleditsch, 'Identity and Conflict: Ties that Bind and Differences that Divide', European Journal of International Relations, 12:1 (2006) 53-87.

20 On the reception Huntington received in Estonia, see, Merje Kuus, 'European Integration in Identity Narratives in Estonia: A Quest for Security', Journal of Peace Research, 39:1 (2002), pp. 91-108. On the frequent invocation of Huntingtonian assumptions and arguments during the Bosnian conflict, see, Lene Hansen, 'Past as Preface: Civilizational Politics and the "Third" Balkan War', Journal of Peace Research, 37:3 (2000), pp. 345-62. 
were not without basis in that over the years, extremists in the Muslim World have mirrored the clash thesis in calling on the Muslims to unite behind the cause of jihad, revive the Islamic civilisation, and rise against the West.

The efforts of those who sought to prevent what they feared was an impending clash culminated in the Fall of 1998 with UN member states declaring the year 2001 as 'UN Year of Dialogue among Civilizations'. ${ }^{21}$ 'Dialogue among civilizations is an absolute imperative'22 said Iranian President Khātamī (1997-2005), one of the major players behind the proposal. Contextualising the need for dialogue in the process of globalisation and increase in peoples' awareness of their differences in present-day world politics, Khātamī offered the UN initiative as an attempt to minimise the efficacy of the clash thesis in shaping policy.

Khātamī's term in presidency has since come to an end. While the former Iranian president continues to pursue DoC through his Geneva-based Foundation, current Iranian leadership does not seem as committed to civilisational dialogue. ${ }^{23}$ Still, Khātamī's vision for ordering the world through civilisational dialogue is alive albeit in a different guise: 'Alliance of Civilizations' initiative sponsored jointly by Spain and Turkey under the auspices of the UN and supported by both the European Union and the Vatican. ${ }^{24}$

Alliance of Civilisations was first presented to the United Nations by Spanish Prime Minister Zapatero. Following UN Secretary General Annan's advice, Spain invited Turkey to co-chair the initiative. ${ }^{25}$ Prime Minister Erdoğan responded positively to the Spanish invitation and assumed co-chairmanship of the Alliance of Civilisations in $2006 .^{26}$ This was not the first time that Turkey was involved in civilisational dialogue. In 2002, Foreign Minister Cem had hosted in İstanbul a joint meeting of the leaders of the European Union and the Organization of Islamic Conference (OIC-EU Joint Forum). ${ }^{27}$

Among state level proponents of DoC, one can count Iran under President Khātamī, the Czech Republic under President Havel, ${ }^{28}$ as well as Spain and Turkey. Over the years, the United Nations (UN), United Nations Educational, Scientific, and Cultural Organization (UNESCO), ${ }^{29}$ European Union (EU), and the Vatican have also expressed support. Among non-state proponents, there is the World Public Forum's

21 Further information on this initiative is available at: $\{$ http://www.un.org/Dialogue/\} accessed 19 September 2011.

22 Quoted in: John L. Esposito and John O. Voll, 'Islam and the West: Muslim Voices of Dialogue', in Pavlos Hatzopoulos and Fabio Petito (eds), Religion in International Relations: The Return from Exile (London: Palgrave Macmillan, 2003), p. 250.

23 The former president's dialogue-themed addresses have since then been removed from the website of the Iranian representation to the UN.

24 For the 'Alliance of Civilizations' initiative, see \{http://www.unaoc.org/\} accessed 17 January 2012.

${ }^{25}$ Laia Mestres and Eduard Soler i Lecha, 'Spain and Turkey: A Long-Lasting Alliance in a Turbulent Context?', Insight Turkey, 8:2 (2006), pp. 117-26.

26 One factor behind PM Erdoğan's wholehearted embrace of DoC was his chief foreign policy advisor Ahmet Davutoğlu (present minister of foreign affairs) who has written extensively on civilisations in a previous life as a professor of International Relations. See, for example, Ahmet Davutoğlu, Civilizational Transformation and the Muslim World (Mahir Publications, 1994); Ahmet Davutoğlu, 'Medeniyetlerin Ben-idraki [Self-cognition of Civilizations]', Divan Ilmi Arastırmalar Dergisi, 1 (1997), pp. 1-53.

27 \{http://www.mfa.gov.tr/brief-summary-of-the-proceedings-of-the-oic-eu-joint-forum.en.mfa\} accessed 19 September 2011.

28 As Petito notes, President Havel did not use DoC formulation. He is nevertheless counted among the proponents of DoC by virtue of the content of his message. See, Fabio Petito, 'The Global Political Discourse of Dialogue among Civilizations: Mohammad Khatami and Václav Havel', Global Change, Peace \& Security, 19:2 (2007), pp. 10-26.

29 \{www.unesco.org/dialogue/index/html\} accessed 25 July 2012. 
'Dialogue of Civilizations', which defines itself as a 'deliberative-consultative body'; 30 former Iranian President Khātamî̀s dialogue foundation; ${ }^{31}$ and 'ResetDOC (Dialogue on Civilizations)' a web magazine set up by an Italian non-profit association based in Rome. ${ }^{32}$ Since then, proponents of DoC initiatives have established grounds for communication where none existed; nurtured inter-faith conversations where possible; and, perhaps most importantly, showed that inter-state interaction could aim for more than the dichotomy of diplomacy vs. use of force. ${ }^{33}$

\section{Civilisation}

This section argues that the proponents of DoC, as they sought to prevent a clash, have bracketed civilisation. In doing so, they have offered a correction in terms of highlighting the peaceful essence of civilisations and the potential for peaceful relations between civilisations. Yet at the same time, DoC initiatives have failed to do away with the essentialism of the clash thesis or the notion of civilisations as autochthonous entities.

The notion of civilisation on which the clash thesis rests is essentialist because Huntington attributes civilisations a primordial essence, which, in turn, renders particular societal characteristics and institutional arrangements 'natural' and 'eternal'. In contrast to such essentialism are 'relationist' 34 and 'dialectical'35 approaches that view civilisations as mutually constituted and always in motion. While relationism looks at civilisations as 'unfolding processes and projects, sets of social practices that serve to draw and re-draw boundaries between entities', ${ }^{36}$ the dialectical approach sees 'relatively dichotomous transformations of multi-layered, differently paced, contradictory and synthetic developments' - as opposed to, that is, 'presumably coherent, religiously unified, and often exclusive civilizational entities that appear in Huntington's pages' ${ }^{37}$

In conjunction with Huntington's essentialism is his understanding of civilisations as autochthonous entities. This assumption crystallises in Huntington's depiction of the 'West':

The West differs from other civilizations in the distinctive character of its values and institutions. These include most notably its Christianity, pluralism, individualism, and rule of law, which made it possible for the West to invent modernity, expand throughout the world, and become the envy of other societies. In their ensemble these characteristics are peculiar to the West ... They make Western civilization unique, and Western civilization is valuable not because it is universal but because it is unique. ${ }^{38}$

30 \{http://www.wpfdc.org/\} accessed 17 January 2012.

31 http://dialoguefoundation.org/\} accessed 17 January 2012

32 \{www.reset.org\} accessed 17 January 2012.

33 Lynch, 'The Dialogue of Civilisations and International Public Spheres', pp. 337-50; Dallmayr, Dialogue Among Civilizations; Esposito and Voll, 'Islam and the West'; Petito, 'The Global Political Discourse of Dialogue among Civilizations'; Petito, 'Dialogue of Civilizations As An Alternative Model for World Order'.

34 Patrick Thaddeus Jackson, “'Civilization”, on Trial', Millennium: Journal of International Studies, 28:1 (1999), p. 142.

35 Hayward R. Alker, 'If Not Huntington's “Civilizations”' Then Whose?', Review (Fernand Braudel Center), XVIII:4 (1995), pp. 533-62.

36 Jackson, "Civilization" on Trial', p. 142.

37 Alker, 'If Not Huntington's “Civilizations”, Then Whose?', p. 534.

${ }^{38}$ Huntington quoted in John M. Hobson, 'The Myth of the Clash of Civilizations in Dialogical-Historical Context', in Pinar Bilgin and Paul D Williams (eds), Global Security, in Encyclopedia of Life Support Systems (EOLSS) \{www.eolss.net\}. 
What allows such portrayals of the Western civilisation to prevail, according to John Hobson, is Eurocentrism. Huntington's Eurocentrism is evident in 'his belief that the West developed in its own unique or exceptional institutions, which enabled it to rise to the top entirely of its own accord'. ${ }^{39}$ Furthermore, Huntington attributes agency to the Western civilisation in the evolution of what is popularly referred to as the civilised way of life while overlooking the contributions of others. ${ }^{40}$ As such, Huntington does not only view civilisations as autochthonous entities but also in terms of a hierarchy, with the West sitting on top of the civilisational ladder. ${ }^{41}$ As will be argued below, while DoC initiatives have, in principle, rejected such hierarchical portrayals of world civilisations, they have nevertheless been built on a notion of civilisation that is not very different from the clash thesis.

First, DoC notion of civilisation, too, is essentialist. Major proponents of DoC define civilisations along religious lines; take religions as unified entities; and believe in an unchanging religious essence that could be revived in the peaceful environment dialogue would allow. Pope Benedict XVI for example, foresees dialogue as taking place between pre-given entities that meet each other to exchange ideas and, if possible, find common ground. In the famous Munich Paper of 2004, Pope Benedict XVI (then Cardinal Ratzinger) wrote:

For Christians, this dialogue would speak of the creation and the Creator. In the Indian world, this would correspond to the concept of 'dharma', the inner law that regulates all Being; in the Chinese tradition, it would correspond to the idea of the structures ordained by heaven. ${ }^{42}$

A similar outlook was also evident in President Khātamì's characterisation of the ideal process of dialogue: '[absorbing] good qualities of the West while rejecting its negative aspects' 43 - his presumption being whatever is 'good' and/or 'negative' about the West or Islam is in their 'essence' (but not in historical processes of coconstitution). Turkey's Prime Minister Erdoğan exhibited a similar attitude toward dialogue in his address to students leaving for abroad to conduct postgraduate studies. He said: 'The poet who penned the Turkish national anthem [Mehmet Akif Ersoy] said that we should compete with the West in art and science; but unfortunately we got the West's immoralities, which are contrary to our values.' ${ }^{44}$ All three prominent proponents of civilisational dialogue determine what to pick and choose in the process of dialogue based on the assumption that there is a religious essence to civilisations; that such essence remains unchanging; and what need reviving through dialogue are

39 John M. Hobson, 'Deconstructing the Eurocentric Clash of Civilizations: De-Westernizing the West by Acknowledging the Dialogue of Civilizations', in Martin Hall and Patrick Thaddeus Jackson (eds), Civilizational Identity: The Production and Reproduction of 'Civilizations' in International Relations (New York: Palgrave Macmillan, 2007), p. 153.

40 In contrast to such monological readings of the history of civilisations is Hobson's dialectical reading that reveals centuries of co-constitution (see the next section for further discussion).

41 John M. Hobson, The Eurocentric conception of world politics: Western international theory, 1760-2010 (Cambridge: Cambridge University Press, 2012). esp. chap. 11.

42 Quoted in Hevdelien, 'Post-secular Consensus?', p. 113. On Pope Benedict XVI's notion of civilisation and practices of dialogue, see Luca Mavelli, Europe's Encounter with Islam: The Secular and the Postsecular (Abingdon: Routledge, 2012), pp. 115-23.

43 Khatami as quoted in Esposito and Voll, 'Islam and the West', p. 254.

44 'Erdoğan, 'Batının Ahlaksızlıklarını Aldık' [Erdoğan: “We Got the West's Immoralities']', Milliyet, 24 January 2008. 
techniques and technologies so that such essence can once again be brought to bear on one's own peoples. ${ }^{45}$

Second, proponents of DoC, too, assume civilisations to be autochthonous entities. Even as they acknowledge civilisational interaction, they imagine such give-and-take to be happening at the fringes. Consider the following quote by President Khātamī:

Civilizations rise and fall ... Unless they are completely unaware of each other's existence, civilizations ordinarily affect and transform one another ... Give-and-take among civilizations is the norm of history ... Thus 'new' civilizations are never new in the true sense, for they always feed on the work of previous civilizations, appropriating and digesting all that fits their needs, dispensing with all that does not. ${ }^{46}$

Through portraying interaction between civilisations as taking place 'only at their edges' 47 DoC initiatives have thereby left intact the pre-given notion of civilisations as religiously unified autochthonous entities.

Indeed, DoC initiatives, even when they portray the West with reference to its secular achievements, still define it in terms of a religious heritage in that they view secularism to be a feature of the Judeo-Christian tradition that others are presumed to lack. ${ }^{48}$ Even as they hail the non-West, they do this by portraying its positive aspects as isolated to religious beliefs and texts alone. Such dichotomisation of civilisations in terms of their spiritual vs. rational past/present, in turn, (re)institutes a hierarchy of civilisations that DoC initiatives have otherwise sought to move away from. Such hierarchy is evident in former Czech President Havel's words quoted below:

if the East can borrow democracy and its inherent values from the West as a space in which a reawakening sense of the transcendental can restore authority, then the West can learn from the East what true authority is, what it grows from, and how it conducts itself. ${ }^{49}$

Even as he envisions a scheme of give and take between civilisations, Havel institutes a hierarchical relationship. Whereas the East is portrayed as exemplary in terms of being in touch with its spiritual roots, the West is not viewed as wholly deficient on that ground. The transcendental, stresses Havel, has roots in the West that could be revived. However, when it comes to ownership of democracy, Havel sees no level playing field. While he portrays the West as having ownership of democracy, the East is represented as in clear need for 'borrowing'. However, as Amartya Kumar Sen has reminded time and again,

there is no empirical reason at all why all champions of the Muslim past, or for that matter of the Arab heritage, have to concentrate specifically on religious beliefs only, and not also on science and mathematics, to which Arab and Muslim societies have contributed so much, and which can also be a part of a Muslim or an Arab identity. ${ }^{50}$

45 This is a process Ahmet Davutoğlu depicts as ben-idraki (self-cognition). See the following section for a discussion on how this notion of DoC is not in tune with the ethics or epistemology of dialogical approaches in the Bakhtinian sense.

46 Quoted in Esposito and Voll, 'Islam and the West', p. 254.

47 Hobson, 'The Myth of the Clash of Civilizations in Dialogical-Historical Context'.

48 On two traditions of secularism, namely Judeo-Christian secularism and laicism, see Elizabeth Shakman Hurd, The politics of secularism in international relations (Princeton: Princeton University Press, 2008).

49 Quoted in Petito, 'The Global Political Discourse of Dialogue among Civilizations', p. 121.

50 Amartya Kumar Sen, Identity and violence: the illusion of destiny (New York: W. W. Norton \& Co., 2006), p. 15. Also see his: Amartya Kumar Sen, The argumentative Indian: writings on Indian history, culture, and identity (New York: Farrar, Straus and Giroux, 2005). 
The point being, bracketing civilisation has the effect of constraining as opposed to fostering dialogue. For, when people are encouraged to find themselves solely in their religious heritage, the pluralism and power/knowledge dynamics within civilisations are often left unacknowledged (see the final section), and they are less likely to seek common ground when conducting dialogue on issues that are ostensibly not a part of their heritage (as with human rights).

\section{Dialogue}

As they bracketed civilisation, proponents of DoC have concentrated their efforts on fostering dialogue. In doing so, they have aspired to a radically different vision of world order than allowed by the clash thesis. Indeed as Marc Lynch has highlighted, whereas the clash thesis rested on the 'realist assumption that no public sphere existed which would enable meaningful communication between civilizations', DoC initiatives have claimed an 'international public sphere within which communicative action might take place'. ${ }^{51}$ This section of the article submits that the promise for fostering dialogue between civilisations is likely to remain unfulfilled unless the notion of 'dialogue' is further fleshed out. ${ }^{52}$

Arguably, the notion of dialogue on which DoC initiatives rest has remained unelaborate because replacing 'clash' with 'dialogue' was considered enough of an improvement upon otherwise grim prospects for world order offered by the clash thesis. Be that as it may, dialogue and clash are not the total opposites they are understood to be in everyday terms. It is possible to have a dialogue in and through violent clashes (as with dialogue and learning that took place during the Crusades). Conversely, it is possible to maintain a monologue while purportedly engaging in dialogue (as with the Israelis and Palestinians during the peace talks held in the immediate aftermath of the first Gulf War). ${ }^{53}$ Fostering dialogue, then, entails further elaboration on the notion of dialogue. In offering this argument, this section of the article builds upon Xavier Guillaume's study on Bakhtinian distinction between dialogical and monological. ${ }^{54}$

In Bakhtinian terms, dialogical utterances are defined by the extent to which they take 'the other' into account. Whereas monologism 'denies the existence outside itself of another consciousness with equal rights and equal responsibilities, another I with equal rights', dialogism is characterised by transgradience whereby 'the self alone cannot feel itself within its own realm of existence, since, according to the idea of transgradience (constitutive of dialogism), a person truly is herself only to the extent

\footnotetext{
51 Lynch, 'The Dialogue of Civilisations and International Public Spheres', p. 311.

52 On different kinds of dialogue as applied to IR, see Knud Erik Jorgensen and Morten Valbjorn, 'Four dialogues and the funeral of a beautiful relationship: European studies and new regionalism', Cooperation and Conflict, 47:1 (2012), pp. 3-27.

53 The deadlock brought about by monological practices of 'dialogue' was broken by the Oslo talks in 1993.

54 Xavier Guillaume, 'Foreign Policy and the Politics of Alterity: A Dialogical Understanding of International Relations', Millenium: Journal of International Studies, 31:1 (2000), pp. 1-26. On Bakhtin, also see, Iver B. Neumann, Uses of the Other: 'the East' in European Identity Formation (Minneapolis: Minnesota University Press, 1999); Iver B. Neumann, 'International relations as emergent Bakhtinian dialogue', International Studies Review, 5:1 (2003), pp. 137-40.
} 
that she can integrate the regard of the other'. ${ }^{55}$ In this sense, dialogue is both an ethical and an epistemological practice. Whereas

[m]onological utterances ... stand on an unsound ethical and epistemological position. In fact, they tend to subvert the other, and do not allow it a proper conscience that is reflexively identical to them. Within a monological figuration, the other becomes an object of the self's own conscience, which can be interpreted and modified at will as a function of the self's own needs as an identity. ${ }^{56}$

The point being, the manner of dialogue DoC initiatives have aspired to foster has been less than dialogical in above-elaborated Bakhtinian sense. This may come across as paradoxical in that forthcoming proponents of DoC have avowedly expressed interest in finding oneself in the other. Consider the following quote by President Khatami:

One goal of dialogue among cultures and civilizations is to recognize and understand not only cultures and civilizations of others, but those of 'one's own'. We could know ourselves by taking a step away from ourselves and embarking on a journey away from self and homeland and eventually attaining a more profound appreciation of our true identity. It is only through immersion into another existential dimension that we could attain mediated and acquired knowledge of ourselves in addition to the immediate and direct knowledge of ourselves that we commonly possess. Through seeing others we attain a hitherto impossible knowledge of ourselves. ${ }^{57}$

Be that as it may, dialogism cannot flourish unless it is adopted as ethics and epistemology. As Mustapha Kamal Pasha has underscored, 'recognition of change and changeability ... without deconstructing the logic of Western historicism only offers a halfway house'. ${ }^{58}$ Such deconstruction calls for a dialogical epistemology in understanding civilisations. DoC initiatives, however, have built upon a monological epistemology.

A dialogical epistemology would allow dialogues between past and present. As opposed to, that is, seeking dialogue in the present as if no such dialogue was/is possible in/with the past (in DoC). To quote Guillaume:

Dialogism represents the interweaving of utterances that respond to one another, an utterance being characterised by its expression, its context and its relation to other utterances, whether this relation is present and/or past, active or passive. ${ }^{59}$

In contrast to DoC's monological epistemology, which does not acknowledge past encounters other than surface interaction and assumes ideas and institutions having a single point of origin, adopting a dialogical epistemology has allowed John M. Hobson to uncover already existing dialogue between civilisations. In his appositely titled book, Eastern Origins of Western Civilization, Hobson wrote:

55 Guillaume, 'Foreign Policy and the Politics of Alterity, p. 8. On dialogue as ethical practice, also see Mavelli, where the author builds upon Martin Buber, one of the inspirations for Bakhtinian dialogism: Mavelli, Europe's encounter with Islam: the secular and the postsecular, pp. 141-45.

56 Guillaume, 'Foreign Policy and the Politics of Alterity', p. 9.

57 Quoted in Petito, 'The Global Political Discourse of Dialogue among Civilizations', p. 111. Compare with: Davutoğlu, 'Medeniyetlerin Ben-idraki [Self-cognition of Civilizations]'.

58 Mustapha Kamal Pasha, 'Civilizations, Postorientalism, and Islam', in Martin Hall and Patrick Thaddeus Jackson (eds), Civilizational identity: the production and reproduction of 'civilizations' in international relations (London: Palgrave Macmillan, 2007), p. 70.

59 Guillaume, 'Foreign Policy and the Politics of Alterity', p. 8. 
The East enabled the rise of the West through two main processes: diffusionism/assimilationism and appropriationism. First, the Easterners created a global economy and a global communications network after 500 along which the more advanced Eastern 'resource portfolios' [for example, Eastern ideas, institutions and technologies] diffused across to the West, where they were subsequently assimilated, through what I call oriental globalisation. And second, Western imperialism after 1492 led the Europeans to appropriate all manner of Eastern economic resources to enable the rise of the West. In short, the West did not autonomously pioneer its own development in the absence of Eastern help, for its rise would have been inconceivable without the contribution of the East. ${ }^{60}$

What is at stake in adopting dialogism as both ethics and epistemology is more than uncovering historical debts, but DoC initiatives' ability to fulfil the promise of fostering dialogue. That co-constitution of civilisations took place centuries ago does not render it mere academic curiosity that is inconsequential for present-day policies and politics. In pursuing this line of argument, I part ways with Fabio Petito who has maintained that

the retrieving of the shared world historical heritage can be politically important, but it does not equate to the retrieving, re-actualisation and mobilisation of the social ethics of the great civilizational and religious traditions of the world. ${ }^{61}$

Be that as it may, adopting a dialogical epistemology reveals how 'the social ethics of the great civilizational and religious traditions of the world'62 have not developed autochthonously but have co-constituted throughout history. ${ }^{63}$ What is at issue, then, is not merely the retrieval of a common heritage but, even more importantly, recognising multiple civilizations' contributions to what are popularly portrayed as 'Western' ideas and institutions.

Writing ideas and institutions such as human rights and democracy out of the heritage of civilisations other than 'the West' does not only render invisible others' contributions to the making of such ideas and institutions, but also ends up substantiating the extremists' theses. For, assumptions regarding ideas and institutions (such as democracy and human rights) having a single (Western) point of origin have warranted Huntingtonians' calls for strengthening their own vis-à-vis the non-West and Muslim extremists' cautions against Western plots to export 'alien' values to the Muslim world. The point being, in the absence of dialogical approaches to civilisations and dialogue, the promise of fostering dialogue is likely to remain unfulfilled.

Such an outcome may come across as paradoxical in that the very purpose of pursuing a Dialogue of Civilisations was to render differences between political actors less existential and more interest-based. ${ }^{64}$ However, in the absence of due recognition of multiple agencies in the emergence of ideas and institutions that are otherwise portrayed as exclusively 'Western' inventions, dialogue would be difficult to foster. Approaching the notion of dialogue as both ethics and epistemology would help fulfil DoC promise of fostering dialogue.

60 John M. Hobson, The Eastern origins of Western civilization (Cambridge: Cambridge University Press, 2004), pp. 2-3.

61 Petito, 'In Defence of Dialogue of Civilizations', p. 766.

62 Ibid.

63 Alker, 'If Not Huntington's “Civilizations”, Then Whose?'.

${ }^{64}$ Lynch, 'The Dialogue of Civilisations and International Public Spheres'. 


\section{Security}

The foregoing has argued that DoC initiatives suffer from significant limitations in their conceptualisation of civilisation and dialogue, thereby rendering unfulfilled the promise of fostering dialogue. This eventuality does not bode well for addressing insecurities identified by the proponents of $\mathrm{DoC}$, that is, violent clashes between states belonging to different civilisations.

Another limitation of DoC initiatives becomes apparent when judged by the standards of critical approaches to security, whereby DoC conception of security is found wanting in terms of both breadth and depth. In what follows, the article highlights insecurities that are likely to remain unidentified and unaddressed in the process of seeking security through DoC.

Before pursuing this argument further, it is important to underscore that proponents of DoC are not unaware of insecurities experienced by non-state referents. Rather, they unambiguously choose to prioritise a statist and military-focused notion of security, which they practice through seeking to maintain the stability of interstate order. Fred Dallmayr, a forthcoming academic proponent of DoC initiatives has justified DoC choice for instituting such a hierarchy of insecurities and referents by alluding to the risks involved in a clash:

Apart from ethical considerations ... there is also a concrete pragmatic consideration in its favour: in the long run [Dialogue of Civilisations] offers the only viable alternative to military confrontation with its ever-present danger of nuclear holocaust and global self-destruction. ${ }^{65}$

The following is not meant to underplay the risks involved, but to highlight those insecurities that are tied up with the institution of such hierarchies of insecurities and referents as such.

We need look no further than the Cold War to see an earlier instance of such a hierarchy. During the Cold War, the threat of nuclear exchange between the two superpowers was put on the top of the security agenda, thereby privileging stability in superpower relations. Those who sought to push other insecurities onto the agenda (practitioners included the Non-Aligned Movement [NAM] or those who called for a New International Economic Order [NIEO]; feminists and environmentalists gained ground both in the academia and social movements) were disciplined into accepting this hierarchy. Those who refused to buy into the Cold War hierarchy were labelled 'naïve' at best. 66

In present-day context, proponents of DoC who push for civilisational dialogue as an urgent remedy for what they fear to be an impending clash institute a similar hierarchy of insecurities and referents. In so doing, they privilege the security of states and marginalise insecurities experienced by non-state referents. What warrants such a hierarchy is a narrow and shallow notion of security (again, reminiscent of the Cold War). ${ }^{67}$

65 Dallmayr, Dialogue Among Civilizations, p. 21.

66 On Cold War in/security hierarchies, see, for example, J. Ann Tickner, Gender in International Relations: Feminist Perspectives on Achieving Global Security (New York, NY: Columbia University Press, 1992); Ken Booth, 'Security and self: reflections of a fallen realist', in Keith Krause and Michael C. Williams (eds), Critical security studies: concepts and cases (Minneapolis: University of Minnesota Press, 1997), pp. 83-119.

67 Pinar Bilgin, Ken Booth, and Richard Wyn Jones, 'Security Studies: The Next Stage?', Nacao e Defesa, 84 (1998), pp. 137-57. 
DoC notion of security is narrow in that the challenge of post-secularism is understood by its proponents in terms of a potential for a violent clash between states belonging to different civilisations. Accordingly, the kind of security DoC initiatives practice is a search for maintaining the stability of inter-state order understood in military-focused and statist terms.

DoC notion of security is also shallow in that its proponents do not elaborate on security as a derivative concept; as deriving from 'different underlying understandings of the character and purpose of politics' ${ }^{68} \mathrm{DoC}$ failure to consider one's role in the production of insecurities as such overlooks ethics already embedded in their practices even as they seek to inject 'ethics' into world politics. ${ }^{69}$ Put differently, DoC initiatives overlook the potential consequences of ordering the world around assumptions of ontological difference at the civilisational level while assuming civilisations to be unified (religiously and otherwise). Such assumptions of internal sameness and failure to recognise one's own culpability in the production of insecurity would result in leaving myriad insecurities unidentified and unaddressed. Let me consider three concrete instances of such insecurity.

First, adopting a notion of civilisation as a religiously unified entity, without due recognition of power/knowledge dynamics within religions, results in overlooking insecurities that are tied up with such dynamics. For, religion is not a neutral space devoid of politics. By way of adopting this particular notion of civilisation and religion, projects of DoC overlook - what Friedrich Kratochwil referred to as - the 'ambivalent effect of religion on political and social life'. ${ }^{70}$ Whereas

nothing follows from religion as such (conceived as a creed or an assemblage of holy texts), until and unless the practices and institutional features are taken into account. Without analyzing this interpretative struggle and the shifting boundaries between the sacred and the profane, not much can be learned from studying the holy texts or from reading the official pronouncements that recite them as legitimizing source..$^{71}$

Indeed, answering Shirin Ebadi's question 'who defines Islam?'72 is far from being uncontroversial. Thus, in the absence of sociopolitical analyses of religions and civilisations, treating civilisations as religiously unified entities, and religions as politically neutral spaces would not allow inquiring into struggles and conflicts within civilisations (and religions) let alone their implications for myriad security referents. ${ }^{73}$

The second and related instance of insecurity has to do with DoC initiatives rendering authoritative the voices of self-appointed civilisational leaders whose version of that civilisation gets portrayed as 'authentic and real'. ${ }^{74}$ Such portrayals leave individuals and social groups' security at the mercy of self-appointed civilisational leaders who claim to "provide not only the "correct" understanding of the holy texts but authoritatively apply them also to the present circumstances'. ${ }^{75}$ While civilisational

${ }^{68}$ Ken Booth, Theory of World Security (Cambridge: Cambridge University Press, 2008), p. 109.

69 J. Peter Burgess, 'Security as Ethics', PRIO policy brief (2008); J. Peter Burgess, The Ethical Subject of Security: Geopolitical Reason and The Threat to Europe (London: Routledge, 2010).

${ }^{70}$ Kratochwil, 'Religion and (inter-)national politics', p. 113.

71 Ibid., p. 114.

72 Shirin Ebadi, 'Who Defines Islam?', openDemocracy, \{www.opendemocracy.net\} accessed 1 February 2012.

73 It is not only DoC initiatives but also the project of multiculturalism that suffers from such a problem of silence when it comes to internal struggles within civilisations, thereby effacing difference within. For a feminist perspective, see Ebadi, 'Who Defines Islam?'.

74 Lynch, 'The Dialogue of Civilisations and International Public Spheres', p. 324.

75 Kratochwil, 'Religion and (inter-)national politics', p. 132. 
leaders need not be religious leaders, more often than not they invoke religious 'truths' in exercising such leadership. Consider, for instance, a statement by Turkey's dialogue-oriented PM Erdoğan, who responded to the ruling of the European Court of Human Rights on the issue of the headscarf ban at Turkey's universities in the following way: ${ }^{76}$

The court has no say over this matter. It is the ulema who has a right to speak. You should consult with those who belong to that religion, be they Jewish or Christian; you ask them whether this matter is a religious obligation. If it is, you have to respect that. If it is not, that is a different matter, political, ideological. If it is a religious matter, you have to respect that. I have studied this matter. It is a mistake to pass judgement on this matter without consulting the Muslim ulema. ${ }^{77}$

However, as Talal Asad reminds us, 'precisely because there is a disagreement among contemporary pious Muslims as to whether the headscarf is a divinely required accouterment for women, its - religious significance must be [all the more] indeterminate'. ${ }^{78}$

Be that as it may, coalitions between religious leaders, self-proclaimed spokespersons of civilisations and policymakers who justify their decisions by invoking religious 'truths' have already produced insecurities for peoples and social groups. Consider the alliance between the Vatican, Saudi Arabia, and Iran that has shaped the UN's policy on issues related to birth control and use of condoms. ${ }^{79}$ Insecurities for women (high levels of death during child-birth), children (high levels of infant mortality), and others (HIV-AIDS) have followed. The second instance of insecurity I identify, then, occurs when self-appointed leaders of civilisations justify their policy choices with reference to the 'essence' of their civilisation whereby non-state referents find it increasingly difficult to identify with anything other than their ascribed civilisation, voice insecurities other than those identified by their 'civilizational leader', or question the kind of solutions they offer.

A third instance of insecurity tied up with DoC initiatives is that is that they constitute 'a deferral of a genuine recognition, exploration, and engagement of difference'. ${ }^{80}$ This is because DoC initiatives take differences in civilisational identity as a pre-given source of insecurity for inter-state world order. Whereas elaborating security as a derivative concept and inquiring into the ethics of security would allow insight into processes whereby insecurities and identities are (re)produced within (and between, see previous sections) civilisations. Be it religious or ethnic or civilisational, 'identity is not a fact of society' but a 'process of negotiation among people and interest groups' ${ }^{81}$ Correspondingly, to quote Bill McSweeney, 'the security problem is not there because people have separate identities; it may well be the case that they have separate identities because of the security problem'. ${ }^{82}$ The third instance of insecurity identified here is that, by way of treating difference as pre-given and locating difference

76 The court had ruled that the Turkish state was within its rights in banning headscarf from Universities. See $\{$ http://news.bbc.co.uk/2/hi/europe/4424776.stm\} accessed 15 February 2012.

77 'Erdoğan Doktrini [Erdoğan Doctrine]', Milliyet, 16 November 2005.

78 Asad quoted in: Mavelli, Europe's encounter with Islam: the secular and the postsecular, p. 72. While Asad's remark is directed against non-Muslims who pass judgment on Muslim 'religious' symbols, his elaboration on religion as a plural space is relevant for Muslims and non-Muslims alike.

79 Fred Halliday, 'The End of the Vatican', openDemocracy, \{www.opendemocracy.net accessed 1 September 2007.

${ }^{80}$ Inayatullah and Blaney, International Relations and the Problem of Difference.

81 Bill McSweeney, Security, Identity and Interests: A Sociology of International Relations (Cambridge: Cambridge University Press, 1999), p. 239.

82 McSweeney, Security, Identity and Interests, p. 239. 
'outside' without due regard for processes of production of identity/security, DoC initiatives have so far deferred both the problem of difference and ethics of security. Such deferral, in turn, has allowed for insecurities to remain if not become more entrenched within and between civilisations.

To recapitulate, in the absence of sociopolitical insights into plurality and power/ knowledge dynamics within civilisations, seeking security through civilisational dialogue would result in ordering the world outside-in. What I mean by ordering the world outside-in is an outcome of the process whereby the proponents of DoC seek to secure inter-civilisational relations while assuming intra-civilisational dynamics to be characterised by security and remaining oblivious to insecurities produced by the very process. Consequently, insecurities experienced by non-state referents remain unidentified and unaddressed.

\section{Conclusion}

The foregoing has sought to highlight the challenge of post-secularism for world politics by pointing to the limitations of civilisational dialogue initiatives that have been offered as a remedy. Toward this end, the article has: (1) considered the extent to which DoC initiatives are likely to address those insecurities they identify; and (2) pointed to other insecurities that are likely to remain unidentified and unaddressed in the process. Whereas the first evaluates DoC initiatives by their own standards, the second evaluates them by the standards of critical approaches to security. It was argued that DoC initiatives, insofar as they bracket civilisation, under-elaborate dialogue thereby overlooking already existing historical dialogue between civilisations, and privilege the security of inter-state order while deferring the problem of difference and ethics of security, are far from offering a comprehensive response in light of the challenge of post-secularism.

This is not to underestimate the significant contributions dialogue between civilisations could make. Indeed, I join Petito in underscoring the need to

acknowledge something like a fundamental ethical-political crisis linked to the present liberal Western civilization and its expansion, and recognize that dialogue of civilizations seems to enshrine the promise of an answer, or rather to start a path toward an answer. ${ }^{83}$

That said what civilisational dialogue initiatives offer in terms of responding to the challenge of post-secularism is a 'potential'. And, as Kratochwil has highlighted, this is an 'ambivalent' potential due to the 'interpretative struggles' that go on within communities. ${ }^{84}$ Limiting our analysis to politics between civilisations amounts to overlooking the politics that take place within civilisations. Seeking to foster civilisational dialogue without paying due attention to the production of security/identity within and between civilisations is likely to have an uncertain contribution to the security of various referents - particularly those that are deemed 'different'.

Coming to terms with the persistence of the problem of difference in world politics impels us to ponder the question: 'how might we respond to the somewhat or mostly incommensurable visions and traditions of others?'85 While it is important to applaud

83 Petito, 'In Defence of Dialogue of Civilizations', p. 763.

84 Kratochwil, 'Religion and (inter-)national politics'.

85 Inayatullah and Blaney, International Relations and the Problem of Difference, p. 9. Also see, Pasha, 'Civilizations, Postorientalism, and Islam', p. 63. 
DoC call for 'reopening and rediscussion of the core of Western-centric and liberal assumptions upon which the normative structure of the contemporary international society is based', ${ }^{86}$ it is equally critical to recognise multiple agencies in the making of what we presently view as 'Western' ideas and institutions; rethink Western and Islamic civilisations (among others) along non-essentialist lines to allow for further dialogue; and seek sociopolitical insight into the dynamics of intra-civilisational relations. An alternative approach to DoC that elaborates on the notions of civilisation, dialogue, and security whereby the problem of difference and ethics of security are not deferred, would likely have very different implications for the security of individuals, social groups, and states. One ethical question that state-level proponents of DoC have so far not asked is a dialogical question: 'how to be with others without assuming what it is to be or what it is to be other'. ${ }^{87}$

\footnotetext{
86 Petito, 'In Defence of Dialogue of Civilizations', p. 762.

87 Burke paraphrasing Kristeva. See Anthony Burke, Beyond security, ethics and violence: war against the other (New York: Routledge, 2007), p. 105.
} 